\title{
Interventions to Reduce Stigma Related to People who Use Drugs: Systematic Review
}

\author{
Joanna Gonçalves de Andrade Tostes ${ }^{1}$ \\ Rafaela Toledo Dias ${ }^{1}$ (iD \\ Andressa Aparecida da Silva Reis ${ }^{1}$ ii \\ Pollyanna Santos da Silveira ${ }^{1,2}$ (D) \\ Telmo Mota Ronzani
}

\begin{abstract}
Interventions to reduce stigma related to people who use drugs can improve their quality of life and adherence to treatment. This review aimed to identify and analyze studies on interventions to reduce the stigma related to people who use drugs. Searches were performed in the following databases, without period delimitation: PubmMed, APA PsycNET, ScienceDirect, Web of Science, and VHL. Considering secondary referencing, we identified a total of 5,488 records. This review covered 28 articles and was based on PRISMA. Although target audiences comprising students and health professionals were predominant, as well as the use of quantitative methods, sample size and interventions varied among studies. The selected studies present considerable methodological limitations. We concluded that no evidence confirms the effectiveness of the proposed interventions and which of them should continue to be applied for this specific aim. It is essential to invest in approaches other than those traditionally adopted.
\end{abstract}

Keywords: stigma, substance use disorders, psychosocial intervention, systematic review

\section{Intervenções para Redução do Estigma Relacionado às Pessoas que Usam Drogas: Revisão Sistemática}

\begin{abstract}
Resumo: Intervenções para a redução do estigma relacionado às pessoas que usam drogas podem melhorar sua qualidade de vida e adesão ao tratamento. Esta revisão teve por objetivo identificar e analisar estudos de intervenções para reduzir o estigma relacionado às pessoas que usam drogas. Foram realizadas buscas nas bases PubMed, APA PsycNET, ScienceDirect, Web of Science e BVS, sem delimitação de ano. Foram identificados 5.488 registros somados à busca secundária de referências. Esta revisão abrange 28 artigos e foi baseada no PRISMA. Houve variação no tamanho da amostra e intervenções, embora o público-alvo de estudantes e profissionais da saúde e o uso de métodos quantitativos tenham sido predominantes. Limitações metodológicas consideráveis foram identificadas nos estudos. Portanto, conclui-se que não há evidências que permitam inferir que as intervenções propostas são efetivas e quais delas deveriam continuar a ser empregadas para essa finalidade. É imprescindível investir em abordagens distintas das adotadas tradicionalmente.
\end{abstract}

Palavras-chave: estigma, transtornos relacionados ao uso de substâncias, intervenção psicossocial, revisão sistemática

\section{Intervenciones para la Reducción del Estigma Relacionado a las Personas que Usan Drogas: Revisión Sistemática}

\begin{abstract}
Resumen: Las intervenciones para la reducción del estigma relacionado a las personas que usan drogas pueden mejorar su calidad de vida y la adherencia al tratamiento. Esta revisión tuvo como objetivo identificar y analizar los estudios sobre las intervenciones para la reducción del estigma relacionado a las personas que usan drogas. Se realizaron búsquedas en las bases de datos PubMed, APA PsycNET, ScienceDirect, Web of Science y BVS, sin delimitación del año. Se identificaron 5.488 registros sumados a la búsqueda secundaria de referencias. Esta revisión abarca 28 artículos y se basó en PRISMA. Hubo una variación en el tamaño de la muestra y las intervenciones, aunque fueron predominantes el público objetivo de estudiantes y profesionales de la salud y el uso de métodos cuantitativos. Se identificaron limitaciones metodológicas considerables en los estudios. Se concluye que no hay evidencias de que las intervenciones propuestas son efectivas y cuáles deberán seguir siendo utilizadas para este propósito. Es esencial invertir en enfoques distintos de los adoptados tradicionalmente.
\end{abstract}

Palabras clave: estigma, trastornos relacionados al uso de sustancias, intervención psicosocial, revisión sistemática

${ }^{1}$ Universidade Federal de Juiz de Fora, Juiz de Fora-MG, Brazil

${ }^{2}$ Universidade Católica de Petrópolis, Petrópolis-RJ, Brazil

Article derived from the main author's doctoral thesis under the supervision of the fifth and fourth authors, to be defended in 2020 at the Graduate Program in Psychology of the Universidade Federal de Juiz de Fora. Support: This study received financial support from FAPEMIG through the processes BPD-00678-14 and APQ-03256-13, and scholarships granted to the first and second authors. It was also supported by CNPq through the process 439408/2018-0, and productivity grant to the fifth author.

Correspondence address: Joanna Gonçalves de Andrade Tostes. Universidade Federal de Juiz de Fora. Instituto de Ciências Humanas. Centro de Referência em Pesquisa, Intervenção e Avaliação em Álcool \& Drogas. (CREPEIA). Rua José Lourenço Kelmer, s/n - São Pedro, Juiz de Fora-MG, Brazil. CEP 36.036-900. E-mail: joanna@tostes.org
Stigma is a complex phenomenon widely conceptualized throughout history. It is associated-at theoretical and practical level — with constructs such as attitudes, stereotypes, prejudice, discrimination, social distance, labeling, attribution, and social identity (Corrigan, Druss, \& Perlick, 2014; Link \& Hatzenbuehler, 2016; Martinez \& Hinshaw, 2016; Myers \& Twenge, 2018). Among its describing processes, we may stress events that label, stereotype, devalue, and discriminate individuals who have some distinguishable social condition deemed as negative. The presence of such components is determined public stigma. It is manifested whenever an established power relationship favors the stigmatizer and causes the stigmatized to experience status 
loss (Link \& Hatzenbuehler, 2016). Stigmatization is also associated with negative effects on stigmatized people's health and quality of life, by lowering their self-esteem and self-efficacy, limiting their social interaction, and increasing social isolation and unemployment (Nieweglowski, Dubke, Mulfinger, Sheehan, \& Corrigan, 2018 and van Boekel, 2015).

Considering the most stigmatized health conditions among the general population - including students and health professionals - problems arising from the use of alcohol and other drugs stand out (United Nations Office on Drugs and Crime [UNODC] 2018). Stigmatization is a major obstacle in searching general and specialized healthcare services, what compromises individuals' adherence to treatment and causes intense psychosocial damage (Corrigan et al., 2016a, 2016b; Silveira, Tostes, Wan, Ronzani, \& Corrigan, 2018; Stringer \& Baker, 2015).

Stigmatizing attitudes, directly or indirectly, may affect healthcare service users and, consequently, the quality of care provided (Ronzani, Soares, Nery, \& Silveira, 2017; Thornicroft, Deb, \& Henderson, 2016). Such attitudes are widely culturally accepted and even politically endorsed (Gopalkrishnan, 2018; Livingston, Milne, Fang, \& Amari, 2011). Thus, it is fundamental to invest in trainings and interventions aiming at the general public and, mainly, health professionals (Evans-Lacko et al., 2014; Giandinoto, Stephenson, \& Edward, 2018). Reducing the stigma of these professionals has gained increasing notoriety in researches and public agendas (Modgill, Patten, Knaak, Kassam, \& Szeto, 2014). However, given the healthcare underfunding in several countries, strategies with this aim still require considerable advance.

Proposed interventions for reducing stigma apply a range variety of approaches. Yet, the literature suggests three main strategies: contact, education, and protest. Contac refers to a positive interpersonal contact with stigmatized groups, contesting negative attitudes by direct interactions, and reducing desire for social distance. Education aims to demystify socially shared information. Among its benefits, we may stress its low cost and wide reach. In turn, protest aims to reduce stigmatization by adopting legal measures and organizing specific advocacy groups, which may reduce judgments in the media (Corrigan et al., 2014). Although some strategies for reducing stigma are known and often incur low costs, they are still not widely available and evaluated (Oliveira, Martins, Richter, \& Ronzani, 2013).

To identify researches that evaluated interventions for reducing stigma related to people who use drugs, Livingston et al. (2011) performed a systematic review-as in our study. They found that, of the thirteen identified studies, nine applied strategies including education and/or contact with people who use drugs. Regarding interventions effects, most reported positive effects in at least one indicator of the evaluated stigma. The most recent review that we found was the aforementioned, performed eight years ago. Our study sought to update the knowledge in the area.

We performed this systematic literature review considering the relevance of the problem of stigmatizing people who use drugs, the need for developing strategies to manage this situation, and the limited number of studies on interventions identified by the previous review, conducted by Livingston et al. (2011). Our review aimed to identify and analyze studies on interventions to reduce the stigma related to people who use drugs. We intended to offer an overview of the characteristics of the studies and verify their main methodological aspects.

\section{Method}

The protocol that guided this systematic review is called Preferred Reporting Items for Systematic Reviews and MetaAnalyses: The PRISMA statement (Galvão, Pansani, \& Harrad, 2015). PRISMA is internationally recognized and aims to improve the quality of systematic reviews and meta-analysis.

To identify studies that proposed interventions for reducing stigma related to people who use drugs, searches were performed in the databases: PubMed, APA PsycNET, ScienceDirect, Web of Science, and VHL. Databases were selected considering their relevance in the indexing of scientific journals linked to the areas of knowledge assumed by this work, such as health and psychology. The search was performed in 2017. No delimitations were adopted (especially regarding dates) to cover not only most recent studies, but also those that may not have been identified by Livingston et al. (2011). Databases were accessed through the Journal Portal of CAPES, using institutional login.

We adopted the same search strategy for all databases, setting the intersection of three fields from the Boolean AND operator. In each set, the Boolean OR operator was used to combine defined terms. The complete search strategy was as follows: stigma reduction OR intervention studies OR experimental studies OR efficacy OR effectiveness OR evaluation OR changing OR training AND social stigma OR prejudice OR attitudes AND substance related disorders OR drug dependence. To define these terms, we adapted the Medical Subject Headings (MeSH) dictionary of terms and two previous systematic reviews: Livingston et al. (2011), previously described, and van Boekel, Brouwers, van Weeghel, and Garretsen (2013), which analyzed studies that evaluated the stigma of health professionals in the drug area, without performing interventions for reducing it.

Inclusion criteria were: intervention articles aimed to reduce stigma or related constructs regarding people who use drugs; written in Portuguese, English, Spanish, and French. Exclusion criteria were: theoretical articles, literature review, instrument validation, editorials, among others. Table 1 details the exclusion categories.

For analyzing the articles, we adopted the procedure of peer evaluation, by reading and filling checklist in table and forms. A team of 12 members, composed by previously trained professors, and $\mathrm{Ph} . \mathrm{D}$, master, and bachelor degree students, was responsible for evaluating the articles. When peers could not reach consensus, articles were discussed in person at the research group meetings. EndNote Web was used to organize the records. 


\section{Results}

In total, we found 5,488 records in the databases: PubMed (3,869), PsycNET APA (987), ScienceDirect (362), Web of Science (33) and VHL (237). Of them, 37 were excluded by duplication; 5,451 records were assessed based on their abstracts. After evaluation, 5,382 articles did not meet the inclusion criteria and were excluded. That is, their focus was not on evaluating interventions for reducing stigma and/or related constructs. We grouped and categorized these articles according to their main characteristics, described in Table 1.

Table 1

Number of excluded studies by categories

\begin{tabular}{|c|c|c|}
\hline Categ. & Description & $n$ \\
\hline A & Evaluation and description of stigma and related constructs related to people who use drugs & 385 \\
\hline $\mathrm{B}$ & $\begin{array}{l}\text { Evaluation and description of stigma and related constructs related to other groups (e.g. attitudes towards people } \\
\text { with HIV) OR other constructs and people who use drugs (e.g. social support of people who use drugs) OR other } \\
\text { constructs and other groups (e.g. muscle dysmorphia in male bodybuilders) }\end{array}$ & 2,878 \\
\hline $\mathrm{C}$ & $\begin{array}{l}\text { Theoretical studies or literature review on stigma and related constructs (e.g. stigma and pejorative language in } \\
\text { dependence) OR other constructs (e.g. AIDS and law) }\end{array}$ & 1,321 \\
\hline $\mathrm{D}$ & $\begin{array}{l}\text { Interventions to reduce stigma and related constructs related to other groups (Ex. intervention for internalized stigma } \\
\text { among hospitalized veterans) OR interventions on other constructs and related to people who use drugs } \\
\text { (e.g. assertiveness training for adolescents with parents who use drugs) OR interventions on other constructs and related } \\
\text { to other groups (e.g. intervention to improve patient adherence to antidepressants after psychiatric hospitalization) }\end{array}$ & 569 \\
\hline $\mathrm{E}$ & Materials other than articles (e.g. indexes, panels, lists) & 228 \\
\hline
\end{tabular}

Note. Categ $=$ Category.

69 articles, which abstracts suggested the evaluation of interventions for reducing stigma related to people who use drugs, remained for full-text reading. After reading, only 17 articles were considered eligible to compose this work. Among the 52 excluded articles, eight fell under the previously presented exclusion category A, 17 in B, seven in C and 20 in D. Then, we performed a secondary referencing search on the 17 studies, by reading the full articles, and included 11 more studies. Our systematic review was composed by 28 articles.
Our results show that only five of the selected articles are common to the review performed by Livingston et al. (2011). They also show that 15 studies prior to the review of Livingston et al. were not contemplated by their search strategy, but were identified by ours. Conversely, our study strategy did not contemplate eight of the studies identified by Livingston et al. We also identified eight articles published after the first review. Figure 1 shows the flowchart referring to records search, selection, and analyzes.

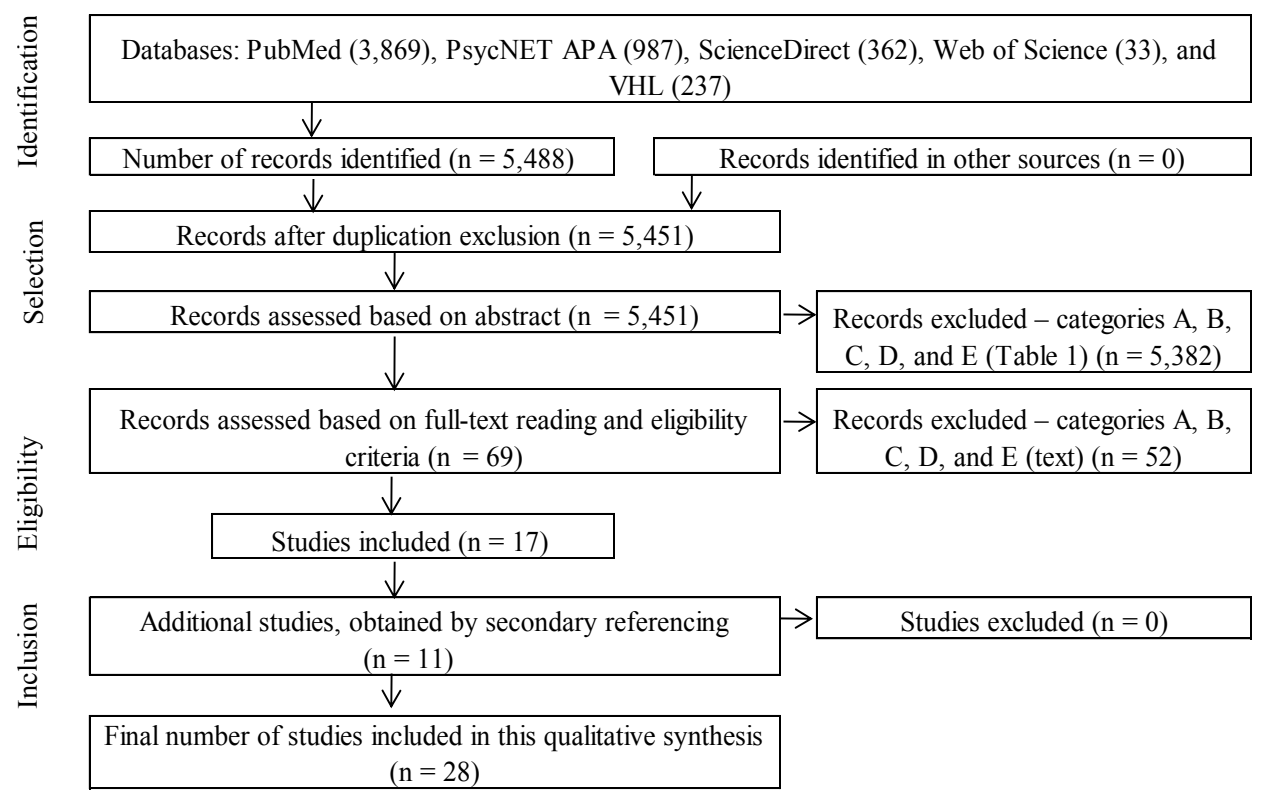

Figure 1. Flowchart of studies identification and selection process. 


\section{Characteristics of studies}

Most of the 28 included studies were conducted in the international context: $18(64 \%)$ in the United States, three $(13 \%)$ in Canada, two (7\%) in Australia, two (7\%) in England, and one (2\%) in Scotland. Only two of them (7\%) were conducted in Brazil (Junqueira, Rassool, Santos, \& Pillon, 2015; Oliveira et al., 2013). Regarding language, all articles were written in English. The years of 2007 and 2013 had the most publications, with four (14\%) each. The most recent work was published in 2015 (Junqueira et al., 2015), and the oldest in 1987 (Chappel \& Veach, 1987).

Our search strategy did not restrict interventions target audience; yet, all identified researches referred to professionals, residents, students, or caregivers in the health area. In total, 21 studies (75\%) comprised students and medical residents, as well as doctors from different specialties, the most common audiences. Other groups targeted by the studies were: nurses, undergraduate and graduate students in nursing $(25 \%)$, professors $(3.6 \%)$, caregivers specialized in treating people who use drugs $(3.6 \%)$, social service professionals (3.6\%), among others that were described as health and primary care professionals (7.1\%). Researches conducted in Brazil comprised nursing students (Junqueira et al., 2015) and primary healthcare professionals (Oliveira et al., 2013).

Sample size varied considerably among studies. The smallest was composed of nine participants (Hettema, Sorensen, Uy, \& Jain, 2009), and the largest by 892 (Gopalan, Santora, Stokes, Moore, \& Levine, 1992). Most studies exclusively adopted a quantitative approach $(n=23 ; 82 \%)$, whereas a single one was exclusively qualitative (Ballon \& Skinner, 2008). Four studies (14\%) used the triangulation of both methods (Crapanzano, Vath, \& Fisher, 2014; Gerace, Hughes, \& Spunt, 1995; Ockene, Wheeler, Adams, Hurley, \& Hebert, 1997; Rose, Stein, Arnsten, \& Saitz, 2006). Only two studies (7\%) did not perform pre- and post-test (Ballon \& Skinner, 2008; Barron, Frank, \& Gitlow, 2012). However, more than half of the studies $(n=16 ; 57 \%)$ did not use a control group.

We observed a great diversity of measurement instruments used to assess stigma. Studies adopted validated and non-validated instruments, elaborated and/or adapted by the authors themselves. The validated instruments most frequently used were: the Alcohol and Alcohol Problems Perception Questionnaire (AAPPQ), the Substance Abuse Attitude Scale (SAAS) and the Drug and Drug Problems Perception Questionnaire (DDPPQ). Most studies $(n=17$; $61 \%$ ) adopted questionnaires elaborated and/or adapted by the authors. Only two studies named the evaluated construct as stigma (Meltzer et al., 2013; Oliveira et al., 2013); the use of attitudes, beliefs, and knowledge was more common.

We also observed a great disparity regarding interventions duration. The shorter intervention was performed in approximately two hours (Ockene et al., 1997), whereas the longer took over three years (Gerace et al., 1995). One article did not specify the duration (Gopalan et al.,1992). Regarding strategies adopted in interventions, the most common were contact with the stigmatized group $(n=9 ; 32 \%)$, technical visits to care services $(n=6 ; 21 \%)$, and role-play with participants to simulate the contact between these professionals and people who use drugs $(n=6 ; 21 \%)$.

All studies adopted, in different ways, educational strategies. Some included didactic sessions regarding screening and diagnostic testing, pharmacology, medical/physiological effects, family problems, community resources (Kokotailo, Langhough, Neary, Matson, \& Fleming, 1995) and substance abuse (Bigby \& Barnes, 1993), as well as legal and ethical questions regarding people who use drugs and information on local and national policies (Munro, Watson, \& McFadyen, 2007). Studies that employed lectures as a teaching method addressed topics such as drug dependence and treatment of alcohol withdrawal, as well as the 12 steps of the Alcoholics Anonymous (AA) (Meltzer et al., 2013; Rose et al., 2006). Studies employed interactive activities involving participants in the form of workshops (Cleary, Hunt, Malins, Matheson, \& Escott, 2009), fostering the connection between general ideas and practical aspects specific to their workplace. Some studies also conducted training modules in Screening, Brief Intervention, and Referral to Treatment (SBIRT) $(n=5 ; 18 \%)$, stimulated discussions of clinical cases $(n=4 ; 14 \%)$, and used audiovisual resources $(n=6 ; 21 \%)$.

As for the ethical aspects, 15 studies (54\%) mentioned the approval of the Research Ethics Committee, whereas 13 $(46 \%)$ did not report this procedure. Table 2 shows the main characteristics of the studies.

Table 2

Characteristics of the articles regarding sample, intervention, and results

\begin{tabular}{|c|c|c|c|}
\hline Authors and year & Sample & Intervention & Main results \\
\hline $\begin{array}{l}\text { Albright, Skipper, Riley, } \\
\text { Wilhelm e Rayburn (2012) }\end{array}$ & $\begin{array}{l}96 \text { medical } \\
\text { students }\end{array}$ & $\begin{array}{l}\text { Education and contact with pregnant } \\
\text { women who use drugs }\end{array}$ & $\begin{array}{l}\text { Increased comfort in talking about drug use and } \\
\text { its negative effects }\end{array}$ \\
\hline Ballon and Skinner (2008) & $\begin{array}{l}28 \text { psychiatric } \\
\text { residents }\end{array}$ & $\begin{array}{l}\text { Education, contact with dependents, } \\
\text { training, group visits }\end{array}$ & Improved attitudes \\
\hline Barron et al. (2012) & $\begin{array}{l}140 \text { doctors and } \\
105 \text { medical } \\
\text { students }\end{array}$ & $\begin{array}{l}\text { Experiential learning at the Summer } \\
\text { Institute for Medical Students }\end{array}$ & $\begin{array}{l}\text { Increased confidence in acknowledging available } \\
\text { resources for dependents and talking about drug } \\
\text { use }\end{array}$ \\
\hline
\end{tabular}


Tostes, J. G. A., Dias, R. T., Reis, A. A. S., Silveira, P. S., \& Ronzani, T. M. (2020). Reducing Drug-Related Stigma: Systematic Review.

Continuation...

Table 2

Characteristics of the articles regarding sample, intervention, and results

\begin{tabular}{|c|c|c|c|}
\hline Authors and year & Sample & Intervention & Main results \\
\hline Bigby and Barnes (1993) & $\begin{array}{l}87 \text { professor } \\
\text { and doctors }\end{array}$ & $\begin{array}{l}\text { Course; role-play, case discussions, } \\
\text { and group meeting }\end{array}$ & $\begin{array}{l}\text { Improved attitudes; increased confidence in } \\
\text { clinical skills }\end{array}$ \\
\hline Bland et al. (2001) & $\begin{array}{l}84 \text { medical } \\
\text { students }\end{array}$ & $\begin{array}{l}\text { Educational modules, simulated } \\
\text { contact with the patient, and lectures }\end{array}$ & $\begin{array}{l}\text { Increased comfort in dealing with patients; } \\
\text { improved attitudes }\end{array}$ \\
\hline Chappel and Veach (1987) & $\begin{array}{l}45 \text { medical } \\
\text { students }\end{array}$ & $\begin{array}{l}\text { Course; discussion groups, clinical } \\
\text { cases, and technical visits }\end{array}$ & $\begin{array}{l}\text { Improved attitudes, unrelated to good clinical } \\
\text { practices }\end{array}$ \\
\hline Cleary et al. (2009) & 32 caregivers & Workshops & $\begin{array}{l}\text { Improved attitudes; greater sympathy; equal } \\
\text { rights to health }\end{array}$ \\
\hline Crapanzano et al. (2014) & 28 doctors & $\begin{array}{l}\text { Teaching and discussions, contact, } \\
\text { and reflective writing }\end{array}$ & $\begin{array}{l}\text { Contact had positive effects, but stigmatizing } \\
\text { attitudes were maintained }\end{array}$ \\
\hline Gabel and Pearsol (1993) & $\begin{array}{l}120 \text { doctors and } \\
\text { nurses }\end{array}$ & Training for professionals & $\begin{array}{l}\text { Improved knowledge and attitudes towards } \\
\text { people who use drugs and with HIV/AIDS }\end{array}$ \\
\hline Gerace et al. (1995) & 32 nurses & $\begin{array}{l}\text { Classes, contact, self-awareness } \\
\text { exercises, role-play, case studies, and } \\
\text { brief intervention }\end{array}$ & $\begin{array}{l}\text { Positive results in the experimental group, } \\
\text { compared to the control group, mainly in the } \\
\text { optimism in treatment }\end{array}$ \\
\hline Gopalan et al. (1992) & $\begin{array}{l}892 \text { medical } \\
\text { students }\end{array}$ & $\begin{array}{l}\text { Elective modules and experiences } \\
\text { related to drug use }\end{array}$ & $\begin{array}{l}\text { Improved attitudes, responsibility, and } \\
\text { knowledge }\end{array}$ \\
\hline Gorman et al. (1990) & $\begin{array}{l}63 \text { health } \\
\text { professionals } \\
\text { and social } \\
\text { workers }\end{array}$ & Education, discussions, and role-play & $\begin{array}{l}\text { No significant improvement in knowledge and } \\
\text { attitudes }\end{array}$ \\
\hline $\begin{array}{l}\text { Heiligman and Nagoshi } \\
\text { (1994) }\end{array}$ & 43 residents & $\begin{array}{l}\text { Classes on dependence and visits to } \\
\text { AA }\end{array}$ & No significant changes in attitudes \\
\hline Hettema et al. (2009) & $\begin{array}{l}9 \text { medical } \\
\text { students }\end{array}$ & $\begin{array}{l}\text { Motivational Enhancement Therapy, } \\
\text { Education, and SBIRT }\end{array}$ & No significant changes in attitudes \\
\hline Junqueira et al. (2015) & $\begin{array}{l}120 \text { nursing } \\
\text { students }\end{array}$ & Theoretical and practical classes & $\begin{array}{l}\text { Improved knowledge and attitudes; experimental } \\
\text { group with greater improvement than control } \\
\text { group }\end{array}$ \\
\hline Kokotailo et al. (1995) & $\begin{array}{l}44 \text { psychiatric } \\
\text { residents }\end{array}$ & $\begin{array}{l}\text { Education, role-play and interviews, } \\
\text { participation in drug assessment and } \\
\text { intervention programs }\end{array}$ & $\begin{array}{l}\text { Improved general knowledge, interest, specific } \\
\text { skills, and trust regarding drugs }\end{array}$ \\
\hline Meltzer et al. (2013) & $\begin{array}{l}128 \text { medical } \\
\text { residents }\end{array}$ & $\begin{array}{l}\text { Knowledge, interactive sessions, } \\
\text { lectures on SBIRT, The Brief } \\
\text { Negotiated Interview (BNI), and } \\
\text { field trip }\end{array}$ & $\begin{array}{l}\text { Increased consideration regarding dependents of } \\
\text { alcohol and pain medications }\end{array}$ \\
\hline $\begin{array}{l}\text { Meng, Rayburn, Ramirez- } \\
\text { Cacho and Rayburn (2007) }\end{array}$ & $\begin{array}{l}117 \text { medical } \\
\text { students }\end{array}$ & Contact with the group & $\begin{array}{l}\text { Improved attitudes; increased comfort with } \\
\text { pregnant patients with alcohol use disorder }\end{array}$ \\
\hline Munro et al. (2007) & 49 nurses & $\begin{array}{l}\text { Groups, education, evidence-based } \\
\text { intervention, ethical issues, and } \\
\text { public policies }\end{array}$ & Improved attitudes in the experimental group \\
\hline Ockene et al.(1997) & $\begin{array}{l}14 \text { doctors, } \\
12 \text { residents, } \\
\text { and } 5 \text { nursing } \\
\text { professionals }\end{array}$ & $\begin{array}{l}\text { Educational strategies, role-play, and } \\
\text { counseling skills }\end{array}$ & $\begin{array}{l}\text { Improved confidence, optimism in treatment, and } \\
\text { stereotyped beliefs }\end{array}$ \\
\hline Oliveira et al. (2013) & $\begin{array}{l}95 \text { primary } \\
\text { healthcare } \\
\text { professionals }\end{array}$ & $\begin{array}{l}\text { SBIRT training for experimental } \\
\text { and control groups, anti-stigma } \\
\text { training for experimental group, and } \\
\text { supervision }\end{array}$ & $\begin{array}{l}\text { No significant differences in the experimental } \\
\text { and control groups stigma }\end{array}$ \\
\hline Puskar et al. (2013) & $\begin{array}{l}319 \text { nursing } \\
\text { students }\end{array}$ & ATN-SBIRT Program and education & $\begin{array}{l}\text { Greater preparation and responsibility; less } \\
\text { motivation to work with patients with alcohol use } \\
\text { disorder }\end{array}$ \\
\hline
\end{tabular}

continues... 
Continuation...

Table 2

Characteristics of the articles regarding sample, intervention, and results

\begin{tabular}{|c|c|c|c|}
\hline Authors and year & Sample & Intervention & Main results \\
\hline $\begin{array}{l}\text { Ramirez-Cacho, } \\
\text { Strickland, Beraun, Meng } \\
\text { and Rayburn (2007) }\end{array}$ & $\begin{array}{l}104 \text { medical } \\
\text { students }\end{array}$ & $\begin{array}{l}\text { Education and contact in clinical } \\
\text { care }\end{array}$ & $\begin{array}{l}\text { Increased comfort in talking about the effects of } \\
\text { drugs and related problems }\end{array}$ \\
\hline Rose et al. (2006) & $\begin{array}{l}36 \text { medical } \\
\text { residents }\end{array}$ & $\begin{array}{l}\text { Educational intervention, lecture } \\
\text { about the AA, and technical visit }\end{array}$ & $\begin{array}{l}\text { Improved attitudes towards AA; greater belief in } \\
\text { its effectiveness }\end{array}$ \\
\hline Salvalaggio et al. (2013) & 300 doctors & $\begin{array}{l}\text { Booklets, online education, } \\
\text { workshops, case studies, SBIRT } \\
\text { training, and contact }\end{array}$ & $\begin{array}{l}\text { Description of the protocol: methodological care } \\
\text { and community challenges }\end{array}$ \\
\hline $\begin{array}{l}\text { Silins, Conigrave, Rakvin, } \\
\text { Dobbins and Curry (2007) }\end{array}$ & $\begin{array}{l}445 \text { medical } \\
\text { students }\end{array}$ & $\begin{array}{l}\text { Lectures, groups, case studies, and } \\
\text { contact }\end{array}$ & $\begin{array}{l}\text { Improved attitudes, especially towards smokers; } \\
\text { lower hatred towards people who use alcohol }\end{array}$ \\
\hline $\begin{array}{l}\text { Strang, Hunt, Generated } \\
\text { and Marsden (2007) }\end{array}$ & 112 doctors & $\begin{array}{l}\text { Training, conferences, and expert } \\
\text { supervision }\end{array}$ & $\begin{array}{l}\text { Improved attitudes; increased group support in } \\
\text { the treatment for people who use drugs }\end{array}$ \\
\hline $\begin{array}{l}\text { Vadlamudi, Adams, Hogan, } \\
\text { Wu and Wahid (2008) }\end{array}$ & $\begin{array}{l}181 \text { nursing } \\
\text { graduate } \\
\text { students }\end{array}$ & $\begin{array}{l}\text { The Brief Negotiated Interview } \\
\text { (BNI), didactic training, and role- } \\
\text { play }\end{array}$ & $\begin{array}{l}\text { Improved attitudes and beliefs; increased } \\
\text { confidence }\end{array}$ \\
\hline
\end{tabular}

\section{Discussion}

This systematic review analyzed studies that performed, in recent decades, interventions to reduce stigma related to people who use drugs. We observed a greater expansion in researches since the 2000s. Such interventions rely on evidence that stigma plays a role in adherence to treatment for both drug dependence or primary healthcare. Engaging people who use drugs in care may improve patient satisfaction with treatment and the quality of interventions (Salvalaggio et al., 2013).

In assessing the methodological quality of the identified studies, we verified some limitations in the proposed interventions regarding their effectiveness and the generalization of their effects. Some studies did not employ a representative number of participants and type of sampling, impairing results from being generalized for other groups and reducing external validity (Cozby \& Bates, 2018). Participants' sociodemographic variables may also have influenced results after the intervention (Hettema et al., 2009; Junqueira et al., 2015; Oliveira et al., 2013; Vadlamudi et al., 2008). The research performed by Barron et al. (2012) presented a low response rate, suggesting that the remaining ones are precisely those with greater improvement in their attitudes.

Meltzer et al. (2013) and Meng et al. (2017), for example, did not randomly distributed their participants to experimental and control groups, hindering the measurement of the actual effect of the interventions, and the control of the contamination effects between groups. The lack of such procedure may attach importance into preexisting differences between groups, reducing study internal validity (Cozby \& Bates, 2018). Experimental and control groups, as well as randomization, play a key role in increasing the internal validity of studies evaluating interventions effects (Ferreira \& Patino, 2016). However, the feasibility of randomization is at stake when considering the challenges and ordinary issues in performing daily assessments in the health context, given the services reality and complex dynamics, as well as logistical and political difficulties (Heard, O'Toole, Naimpally, \& Bressler, 2017).

We also identified that the studies conducted by Meltzer et al. (2013), Meng et al. (2007), and Ramirez-Cacho et al. (2007) did perform post-test, but no long-term follow-up evaluation. Yet, the authors recognize its need for observing whether or not the benefits of the intervention were maintained over time. The review performed by Livingston et al. (2011) also reported that most of the medium and longterm effects of the adopted interventions remained unknown.

By analyzing the studies that compose our review, we verified divergencies among the terminologies used to operationalize the stigma construct. Considering the complexity of the phenomenon, the chosen evaluation methods also reflect the difficulties in measuring it. Most studies adopted non-validated instruments elaborated by the authors themselves. Thus, there was no evaluation of the instruments ability to reproduce a consistent result in time and space - reliability - and its ability to measure exactly what it proposes - validity (Souza, Alexandre, \& Guirardello, 2017). The studies may also present tangible changes that these instruments were unable to measure. These difficulties are even more pronounced by the lack of triangulation. Face-to-face interviews, focus groups, and other methods could help assess changes within stigma indicators. Difficulties in measuring stigma are intensified by the tendency of participants to provide socially desirable responses (Hinshaw, 2015). Two articles (Ballon \& Skinner, 2008; Meltzer et al., 2013) indicated social desirability as a limitation in the study, although it is probable to occur in all studies, to a greater or lesser extent. 
Regarding strategies underpinning interventions to reduce stigma, all studies adopted educational strategies, which may be justified by its low cost and wide reach. A global health promotion for people who use drugs requires a vital investment in training professionals, who are constantly beset by insufficient training, scarce resources, and excessive workloads, limiting them to providing quality care. Consistently, Gopalan et al. (1992) and Vadlamudi et al. (2008) stress the importance of education in improving knowledge and attitudes regarding drug use in nursing students' curricula. Ramirez-Cacho et al. (2007) corroborated these findings regarding medical students, indicating the need to articulate practice and theory. However, some studies reported a certain reluctance in integrating more content about drugs into curricula (Junqueira et al., 2015).

Educational strategies have positive effects on attitudes and behavioral intentions; yet, contact is the strategy for change considered more effective among adults in the general population (Thornicroft et al., 2015) and was underused by the studies evaluated in this review. Among the studies that used contact, they did not adopt it as a central component in the proposed interventions (Ballon \& Skinner, 2008; Chappel \& Veach, 1987; Crapanzano et al., 2014; Gerace et al., 1995; Heiligman \& Nagoshi, 1994; Meltzer et al., 2013; RamirezCacho et al., 2007; Salvalaggio et al., 2013; Silins et al., 2007).

However, evidence has shown that positive contact effects are often found when evaluation is performed immediately after the intervention, so the long-term benefits of this approach are not well-known (Mehta et al., 2015). Interventions must adopt multiple strategies, have longer duration, and encompass different dimensions of attitudes (Bland et al., 2001; Gopalan et al., 1992; Meltzer et al., 2013; Oliveira et al., 2013).

Regarding the analysis of the main effects of the interventions, most studies reported positive changes in the participants, such as: improved attitudes towards people who have drug dependence (Ballon \& Skinner, 2008; Junqueira et al., 2015), increased comfort and confidence in talking to patients about drug use (Albright et al., 2012; Bland et al., 2001; Ramirez-Cacho et al., 2007), increased confidence in clinical skills when recognizing problematic drug use (Bigby \& Barnes, 1993), and improved optimism in treatment and stereotyped beliefs (Ockene et al., 1997).

Conversely, Chappel and Veach (1987) stress that the positive changes observed were not related to good clinical practices. Crapanzano et al. (2014) found a similar result, reporting the difficulty faced by participants in reconciling their beliefs with the content addressed by the intervention, and the maintenance of some stigmatizing attitudes in the post-test. Other studies found no significant changes in participants' attitudes (Gorman et al., 1990; Heiligman \& Nagoshi, 1994; Hettema et al., 2009; Oliveira et al., 2013).

The insufficient findings of these studies indicate and emphasize the need, in issues involving drug use, for a multisectoral and coordinated approach, encompassing a continuum ranging from primary prevention and risk reduction to disorders management, rehabilitation, and harm reduction. For this approach to reach the most vulnerable populations, it must be grounded on the precepts of equality, social justice, and human rights. It must also consider the social determinants of health and person-centered approaches (Stronks, Toebes, Hendriks, Ikram, \& Venkatapuram, 2016). Although the literature suggests that stigma is a determining factor for recovery from drug dependence, studies on this matter are still scarce - especially in comparison to the stigma related to mental illness (Corrigan et al., 2016a, 2016b; Nieweglowski et al., 2018; Silveira et al., 2018).

A possible limitation in our review is that, although it strictly followed the PRISMA guidelines, some studies that meet the inclusion criteria may not have been identified. It may be justified by the adopted search strategy and the used terms, as well as by the indexation to the databases of interventions studies performed by other authors. To mitigate this limitation and the potential selection bias, a key strength of this review was expanding the search strategy and the terms adopted in the review performed by Livingston et al. (2011), besides covering studies written in Portuguese, English, Spanish, and French. During information gathering from primary studies, the evaluation team discussed the findings to resolve disagreements. Our review also advanced in identifying studies published after the review conducted by Livingston et al. (2011), as well as previous works not contemplated by them.

We found indicate methodological problems in the analyzed studies to evaluate interventions effects in reducing stigma related to people who use drugs. Such empirical finding corroborates the methodological and theoretical discussion in the area regarding the limitations imposed by the use of certain instruments - especially self-report - in evaluating the present construct. The strategies for reducing stigma and the methods for its evaluation were inadequate to obtain more definitive results. Our results indicate that evidence-based and effective strategies constitute a major gap in the area, persisting even after decades of theoretical and empirical research.

By performing this methodologically rigorous systematic review - the most extensive and recent regarding interventions to reduce stigma related to people who use drugs, - we concluded that the analyzed studies present no evidence to infer the effectiveness of the proposed interventions and which of them should continue to be applied for this aim. Considering the relevance of the problem, this work is an important data for the field, stressing the need to invest in approaches other than those traditionally adopted in the area of stigma.

\section{References}

Albright, B., Skipper, B., Riley, S., Wilhelm, P., \& Rayburn, W. F. (2012). Medical students' comfort with pregnant women with substance-use disorders: A randomized educational study. Academic Psychiatry, 36(6), 457-460. doi:10.1176/appi.ap.11070134

Ballon, B. C., \& Skinner, W. (2008). Attitude is a little thing that makes a big difference": Reflection techniques for addiction psychiatry training. Academic Psychiatry, 32(8), 218-224. doi:10.1176/appi.ap.32.3.218 
Barron, R., Frank, E., \& Gitlow, S. (2012). Evaluation of an experiential curriculum for addiction education among medical students. Journal of Addiction Medicine, 6(2), 131-136. doi:10.1097/ADM.0b013e3182548abd

Bigby, J., \& Barnes, H. N. (1993). Evaluation of a faculty development program in substance abuse education. Journal of General Internal Medicine, 8(6), 301-305. doi:10.1007/bf02600141

Bland, E., Oppenheimer, L., Brisson-Carroll, G., Morel, C., Holmes, P., \& Gruslin, A. (2001). Influence of an educational program on medical students' attitudes to substance use disorders in pregnancy. American Journal of Drug and Alcohol Abuse, 27(3), 483-490. doi:10.1081/ ada-100104513

Chappel, J. N., \& Veach, T. L. (1987). Effect of a course on students' attitudes toward substance abuse and its treatment. Journal of Medical Education, 62(5), 394-400. doi:10.1097/00001888-198705000-00004

Cleary, M., Hunt, G. E., Malins, G., Matheson, S., \& Escott, P. (2009). Drug and alcohol education for consumer workers and caregivers: A pilot project assessing attitudes toward persons with mental illness and problematic substance use. Archives of Psychiatric Nursing, 23(2), 104-110. doi:10.1016/j.apnu.2008.05.004

Corrigan, P. W., Druss, B. G., \& Perlick, D. A. (2014). The impact of mental illness stigma on seeking and participating in mental health care. Psychological Science in the Public Interest, 15(2), 37-70. doi:10.1177/1529100614531398

Corrigan, P. W., Schomerus, G., Shuman, V., Kraus, D., Perlick, D., Harnish, A., ... Smelson, D. (2016a). Developing a research agenda for understanding the stigma of addictions. Part I: Lessons from the Mental Health Stigma Literature. American Journal on Addictions, 26(1), 59-66. doi:10.1111/ajad.12458

Corrigan, P. W., Schomerus, G., Shuman, V., Kraus, D., Perlick, D., Harnish, A., ... Smelson, D. (2016b). Developing a research agenda for reducing the stigma of addictions. Part II: Lessons from the mental health stigma literature. American Journal on Addictions, 26(1), 67-74. doi:10.1111/ajad.12436

Cozby, P. C., \& Bates, S. C. (2018). Methods in behavioral research (13th ed.). New York, NY: McGraw-Hill Education.

Crapanzano, K., Vath, R. J., \& Fisher, D. (2014). Reducing stigma towards substance users through an educational intervention: Harder than it looks. Academic Psychiatry, 38(4), 420-425. doi:10.1007/s40596-014-0067-1

Evans-Lacko, S., Courtin, E., Fiorillo, A., Knapp, M., Luciano, M., Park A. L., ... Thornicroft, G. (2014). The state of the art in European research on reducing social exclusion and stigma related to mental health: A systematic mapping of the literature. European Psychiatry, 29(6), 381-389. doi:10.1016/j.eurpsy.2014.02.007
Ferreira, J. C., \& Patino, C. M. (2016). Randomização: Mais do que o lançamento de uma moeda [Randomization: Beyond tossing a coin]. Jornal Brasileiro de Pneumologia, 42(5), 310. doi:10.1590/S1806-37562016000000296

Gabel, L. L., \& Pearsol, J. A. (1993). The twin epidemics of substance use and HIV: A state-level response using a train-the-trainer model. Family Practice, 10(4), 400-405. doi:10.1093/fampra/10.4.400

Galvão, T. F., Pansani, T. S. A., \& Harrad, D. (2015). Principais itens para relatar revisões sistemáticas e meta-análises: A recomendação PRISMA. Epidemiologia e Serviços de Saúde, 24(2), 335-342. doi:10.5123/S1679-49742015000200017

Gerace, L. M., Hughes, T. L., \& Spunt, J. (1995). Improving nurses' responses toward substance-misusing patients: A clinical evaluation project. Archives of Psychiatric Nursing, 9(5), 286-294. doi:10.1016/ s0883-9417(95)80048-4

Giandinoto, J. A., Stephenson, J., \& Edward, K. L. (2018). General hospital health professionals' attitudes and perceived dangerousness towards patients with comorbid mental and physical health conditions: Systematic review and meta-analysis. International Journal of Mental Health Nursing, 27(3), 942-955. doi:10.1111/inm.12433

Gopalan, R., Santora, P., Stokes, E. J., Moore, R. D., \& Levine, D. M. (1992). Evaluation of a model curriculum on substance abuse at The Johns Hopkins University School of Medicine. Academic Medicine, 67(4), 260-266. doi:10.1097/00001888-199204000-00014

Gopalkrishnan, N. (2018). Cultural diversity and mental health: Considerations for policy and practice. Frontiers in Public Health, 6, 179. doi:10.3389/fpubh.2018.00179

Gorman, D. M., Werner, J. M., Jacobs, L. M., \& Duffy, S. W. (1990). Evaluation of an alcohol education package for non-specialist health care and social workers. British Journal of Addiction, 85(2), 223-233. doi:10.1111/j.1360-0443.1990.tb03075.x

Heard, K., O’Toole, E., Naimpally, R., \& Bressler, L. (2017). Real-world challenges to randomization and their solutions. Cambridge, MA: J-PAL North America. Retrieved from https:/www.povertyactionlab.org/ sites/default/files/resources/2017.04.14-Real-WorldChallenges-to-Randomization-and-Their-Solutions.pdf

Heiligman, R. M., \& Nagoshi, C. T. (1994). A longitudinal study of family practice residents' attitudes toward alcoholism. Family Medicine, 26(7), 447-451.

Hettema, J. E., Sorensen, J. L., Uy, M., \& Jain, S. (2009). Motivational enhancement therapy to increase resident physician engagement in substance abuse education. Substance Abuse, 30(3), 244-247. doi:10.1080/08897070903041210 
Hinshaw, S. P. (2015). Stigma and mental illness: Developmental issues and future prospects. In D. Cicchetti \& D. J. Cohen (Eds.), Developmental psychopathology: Vol. 3. Risk, disorder, and adaptation (2nd ed., pp. 841-881). Hoboken, NJ: Wiley.

Junqueira, M. A., Rassool, G. H., Santos, M. A., \& Pillon, S. C. (2015). The impact of an educational program in brief interventions for alcohol problems on undergraduate nursing students: A Brazilian context. Journal of Addictions Nursing, 26(3), 129-135. doi:10.1097/JAN.0000000000000086

Kokotailo, P. K., Langhough, R., Neary, E. J., Matson, S. C., \& Fleming, M. F. (1995). Improving pediatric residents' alcohol and other drug use clinical skills: Use of an experiential curriculum. Pediatrics, 96(1), 99-104.

Link, B., \& Hatzenbuehler, M. L. (2016). Stigma as an unrecognized determinant of population health: Research and policy implications. Journal of Health Politics, Policy and Law, 41(4), 653-673. doi:10.1215/03616878-3620869

Livingston, J. D., Milne, T., Fang, M. L., \&Amari, E. (2011). The effectiveness of interventions for reducing stigma related to substance use disorders: A systematic review. Addiction, 107(1), 39-50. doi:10.1111/j.1360-0443.2011.03601.x

Martinez, A. G., \& Hinshaw, S. P. (2016). Mental health stigma: Theory, developmental issues, and research priorities. In D. Cicchetti (Ed.), Developmental psychopathology: Vol. 4. Risk, resilience, and intervention (3rd ed., pp. 997-1039). Hoboken, NJ: Wiley.

Mehta, N., Clement, S., Marcus, E., Stona, A. C., Bezborodovs, N., Evans-Lacko, S., ... Thornicroft, G. (2015). Evidence for effective interventions to reduce mental health-related stigma and discrimination in the medium and long term: Systematic review. The British Journal of Psychiatry, 207(5), 377-384. doi:10.1192/bjp.bp.114.151944

Meltzer, E. C., Suppes, A., Burns, S., Shuman, A., Orfanos, A., Sturiano, C. V., ... Fins, J. J. (2013). Stigmatization of substance use disorders among internal medicine residents. Substance Abuse, 34(4), 356-362. doi:10.1080/ 08897077.2013 .815143

Meng, C., Rayburn, B. B., Ramirez-Cacho, W. A., \& Rayburn, W. F. (2007). Effect of a specialized prenatal clinic on medical student attitudes toward women with drinking problems. The Journal of Maternal-Fetal \& Neonatal Medicine, 20(3), 217-220. doi:10.1080/14767050601057564

Modgill, G., Patten, S. B., Knaak, S., Kassam, A., \& Szeto, A. C. H. (2014). Opening Minds Stigma Scale for Health Care Providers (OMS-HC): Examination of psychometric properties and responsiveness. BMC Psychiatry, 14, 120. doi:10.1186/1471-244X-14-120
Munro, A., Watson, H. E., \& McFadyen, A. (2007). Assessing the impact of training on mental health nurses' therapeutic attitudes and knowledge about co-morbidity: A randomised controlled trial. International Journal of Nursing Studies, 44(8), 1430-1438. doi:10.1016/j.ijnurstu.2006.07.024

Myers, D. G., \& Twenge, J. (2018). Social psychology (13th ed.). New York, NY: McGraw-Hill Education.

Nieweglowski, K., Dubke, R., Mulfinger, N., Sheehan, L., \& Corrigan, P. W. (2018). Understanding the factor structure of the public stigma of substance use disorder. Addiction Research \& Theory, 27(2), 156-161. doi:10.10 80/16066359.2018.1474205

Ockene, J. K., Wheeler, E. V., Adams, A., Hurley, T. G., \& Hebert, J. (1997). Provider training for patient-centered alcohol counseling in a primary care setting. Archives of Internal Medicine, 157(20), 2334-2341. doi:10.100/ archinte.1997.00440410066007

Oliveira, M. C., Martins, L. F., Richter, K., \& Ronzani, T. M. (2013). Evaluation of an intervention to reduce health professional stigma toward drug users: A pilot study. Journal of Nursing Education and Practice, 3(5), 138-148. doi:10.5430/jnep.v3n5p138

Puskar, K., Gotham, H. J., Terhorst, L., Hagle, H., Mitchell, A. M., Braxter, B., ... Burns, H. K. (2013). Effects of Screening, Brief Intervention, and Referral to Treatment (SBIRT) education and training on nursing students' attitudes toward working with patients who use alcohol and drugs. Substance Abuse, 34(2), 122-128. doi:10.1080/08897077.2012.715621

Ramirez-Cacho, W. A., Strickland, L., Beraun, C., Meng, C., \& Rayburn, W. F. (2007). Medical students' attitudes toward pregnant women with substance use disorders. American Journal of Obstetrics and Gynecology, 196(1), 86.e1-5. doi:10.1016/j.ajog.2006.06.092

Ronzani, T. M., Soares, R. G., Nery, F. C., \& Silveira, P. S. (2017). Adaptação transcultural brasileira da escala de estigma internalizado de transtorno mental - ISMI-BR [Brazilian cross-cultural adaptation of the stigma scale of internalized mental illness - ISMI-BR]. Gerais: Revista Interinstitucional de Psicologia, 10(1), 25-34. Retrieved from http://pepsic.bvsalud.org/scielo.php?script=sci arttext\&pid=S1983-82202017000100004

Rose, A. J., Stein, M. R., Arnsten, J. H., \& Saitz, R. (2006). Teaching internal medicine resident physicians about alcoholics anonymous: A pilot study of an educational intervention. Substance Abuse, 27(3), 5-11. doi:10.1300/ J465v27n03_02

Salvalaggio, G., Dong, K., Vandenberghe, C., Kirkland, S., Mramor, K., Brown, T., ... Wild, T. C. (2013). Enhancing screening, brief intervention, and referral to treatment among socioeconomically disadvantaged patients: Study protocol for a knowledge exchange intervention involving patients and physicians. BMC Health Services Research, 13, 108. doi:10.1186/1472-6963-13-108 
Silins, E., Conigrave, K. M., Rakvin, C., Dobbins, T., \& Curry, K. (2007). The influence of structured education and clinical experience on the attitudes of medical students towards substance misusers. Drug and Alcohol Review, 26(2), 191-200. doi:10.1080/09595230601184661

Silveira, P. S., Tostes, J. G. A., Wan, H. T., Ronzani, T. M., \& Corrigan, P. W. (2018). The stigmatization of drug use as mechanism of legitimation of exclusion. In T. M. Ronzani (Ed.), Drugs and social context: Social perspectives on the use of alcohol and other drugs (pp. 15-25). Cham, Switzerland: Springer.

Souza,A. C., Alexandre, N. M. C., \& Guirardello, E. B. (2017). Propriedades psicométricas na avaliação de instrumentos: Avaliação da confiabilidade e da validade [Psychometric properties in instruments: Evaluation of reliability and validity]. Epidemiologia e Serviços de Saúde, 26(3), 649-659. doi:10.5123/s1679-49742017000300022

Strang, J., Hunt, C., Gerada, C., \& Marsden, J. (2007). What difference does training make? A randomized trial with waiting-list control of general practitioners seeking advanced training in drug misuse. Addiction, 102(10), 1637-1647. doi:10.1111/j.1360-0443.2007.01929.x

Stringer, K. L., \& Baker, E. H. (2015). Stigma as a Barrier to substance abuse treatment among those with unmetneed:An analysis of parenthood and marital status. Journal of Family Issues, 39(1), 3-27. doi:10.1177/0192513×15581659

Stronks, K., Toebes, B., Hendriks, A., Ikram, U., \& Venkatapuram, S. (2016). Social justice and human rights as a framework for addressing social determinants of health: Final report of the Task group on Equity, Equality and Human Rights: Review of social determinants of health and the health divide in the WHO European Region. Copenhagen, Denmark: WHO.

Thornicroft, G., Deb, T., \& Henderson, C. (2016). Community mental health care worldwide: Current status and further developments. World Psychiatry, 15(3), 276-286. doi:10.1002/wps.20349

Thornicroft, G., Mehta, N., Clement, S., Evans-Lacko, S., Doherty, M., Rose, D., ... Henderson, C. (2015). Evidence for effective interventions to reduce mental-health-related stigma and discrimination. The Lancet, 387(10023), 1123-1132. doi:10.1016/S0140-6736(15)00298-6

United Nations Office on Drugs and Crime. (2018). World Drug Report 2018: Executive summary conclusions and policy implications (United Nations publication, Sales No. E.18.XI.9). Vienna, Austria: UNODC. Retrieved from https://www.unodc.org/wdr2018/prelaunch/WDR18_ Booklet_1_EXSUM.pdf

Vadlamudi, R. S., Adams, S., Hogan, B., Wu, T., \& Wahid, Z. (2008). Nurses' attitudes, beliefs and confidence levels regarding care for those who abuse alcohol: Impact of educational intervention. Nurse Education in Practice, 8(4), 290-298. doi:10.1016/j.nepr.2007.10.003 van Boekel, L. C. (2015). Stigmatization of people with substance use disorders: Attitudes and perceptions of clients, healthcare professionals and the general public. Enschede, The Netherlands: Ipskamp Drukkers.

van Boekel, L. C., Brouwers, E. P. M., van Weeghel, J., \& Garretsen, H. F. L. (2013). Stigma among health professionals towards patients with substance use disorders and its consequences for healthcare delivery: Systematic review. Drug and Alcohol Dependence, 131(1-2), 23-35. doi:10.1016/j.drugalcdep.2013.02.018

Joanna Gonçalves de Andrade Tostes is a Ph.D. candidate in Psychology at the Universidade Federal de Juiz de Fora, Juiz de Fora-MG, Brazil.

Rafaela Toledo Dias has a Master's degree in Psychology at the Universidade Federal de Juiz de Fora, Juiz de Fora-MG, Brazil.

Andressa Aparecida da Silva Reis has a Bachelor's degree in Psychology at the Universidade Federal de Juiz de Fora, Juiz de Fora-MG, Brazil.

Pollyanna Santos da Silveira is an Assistant Professor in the Department of Psychology at the Universidade Católica de Petrópolis, Petrópolis-RJ, Brazil, and a Collaborating Professor in the Psychology Graduate Program at the Universidade Federal de Juiz de Fora-MG, Brazil.

Telmo Mota Ronzani is an Associate Professor in the Department of Psychology at the Universidade Federal de Juiz de Fora, Juiz de Fora-MG, Brazil.

\section{Authors' Contribution:}

All authors made substantial contributions to the conception and design of this study, to data analysis and interpretation, and to the manuscript revision and approval of the final version. All the authors assume public responsibility for content of the manuscript.

Received: Oct. 09, 2018

1st Revision: Dec. 21, 2018

2nd Revision: May. 01, 2019

Approved: May. 30, 2019

How to cite this article:

Tostes, J. G. A., Dias, R. T., Reis, A. A. S., Silveira, P. S., \& Ronzani, T. M. (2020). Interventions to reduce stigma related to people who use drugs: Systematic review. Paidéia (Ribeirão Preto), 30, 2020, Vol. 30, e3022.doi:https://doi.org/10.1590/1982-4327e3022 